\title{
Politik Hukum Otonomi Daerah Dalam Mewujudkan Tata Kelola Pemerintahan Yang Baik di Bidang Kesehatan
}

\begin{abstract}
Azlan Thamrin
Program Studi Hukum Tata Negara, Fakultas Syariah dan Ilmu Hukum Islam Institut Agama Islam Negeri (IAIN) Parepare

Email: azlanthamrin@iainpare.ac.id

Abstract

The implementation of regional autonomy provides the opportunity for local governments to create progress in many aspects, including in the field of health. The research site is in Bone Regency.The research aimed (1) to investigate and understand the legal politics of the regional autonomy in realizing the good governance in health sector; (2) to investigate and understand the application of the good governance principles in the implementation of the administration affairs of the government.The research was an empirical legal research which usually called a socio-legal research. The research was conducted in the Regional Government of Bone Regency. The research was qualitative and was supported legal materials. The data were analyzed using the descriptive and qualitative content analysis. The research result indicated that (1) the legal policy of the regional autonomy in the realization of the good governance in health sector in Bone Regency was based on right of the health protection; that the government must give the right to every citizen, and the local government of Bone Regency should be involved in the health protection based on the principles of autonomy. That between the local government and the central government there should be a division of authority in order to avoid the overlapping authority. Therefore, the formats of regulatory, funding, and implementation are needed in order that the implementation of the health service could reach the community directly. (2) The application of a good governance in the implementation of the government affairs in the health sector in Bone Regency is measured based on: the community access to the information about the government coordination, the community trust in the government institutions (particularly in the health sector), the consistency of the local government of Bone Regency in enforcing the law when executing the government, and the involvement of the non-governmental elements in the policy making (particularly in the health sector). All these effect satisfaction level of the authority implementation of the local government of Bone regency in the health sector, 20 out of 40 respondents has given their good evaluation in the health sector; that the health service in the regency has been running well.
\end{abstract}

Keywords: Health; Division of the Government Affairs; Local Government

\begin{abstract}
Abstrak
Penerapan otonomi daerah memberikan kesempatan kepada Pemerintah Daerah untuk meciptakan perkembangan di berbagai aspek, termasuk di bidang kesehatan. Penelitian ini dilakukan di Kabupaten Bone, Sulawesi Selatan.Penelitian ini bertujuan mengetahui dan memahami (1) politik hukum otonomi daerah dalam mewujudkan tata kelola pemerintahan yang baik pada bidang kesehatan, dan (2) penerapan prinsip tata kelola pemerintahan yang baik dalam penyelenggaraan urusan pemerintahan pada bidang kesehatan. Penelitian ini merupakan penelitian hukum empiris. Penelitian berlokasi di
\end{abstract}


Jurnal Al-Adalah: Jurnal Hukum dan Politik Islam

Vol. 4, No. 1, Januari 2019:33-51

P-ISSN: 2406-8802

E-mail: aladalah@iain-bone.ac.id

http://jurnal.iain-bone.ac.id/index.php/aladalah

lingkup Pemerintahan Daerah Kabupaten Bone dan dilakukan secara kualitatif. Data dianalisis secara deskriptif kualitatif dengan metode analisis konten. Hasil penelitian menunjukan (1) politik hukum otonomi daerah dalam mewujudkan tata kelola pemerintahan yang baik pada bidang kesehatan di Kabupaten Bone didasari oleh hak atas perlindungan kesehatan bagi setiap warga negara yang mutlak diberikan oleh negara. Pelaksanaannya melibatkan unsur pemerintahan di Kabupaten Bone berdasarkan prinsip otonomi dengan cara membagi urusan pemerintahan antara pemerintah pusat dengan pemerintah daerah agar tidak terjadi tumpang tindih. Oleh karena itu, dibutuhkan format pengaturan, pembiayaan, dan pelaksanaan agar penyelenggaraan kesehatan bisa bersentuhan langsung kepada masyarakat.(2) penerapan prinsip tata kelola pemerintahan yang baik dalam penyelenggaraan urusan pemerintahan pada bidang kesehatan di kabupaten bone di ukur berdasarkan akses masyarakat memperoleh informasi penyelenggaraan pemerintahan, kepercayaan masyarakat terhadap institusi pemerintah (khususnya di bidang kesehatan), konsistensi pemerintah daerah Kabupaten Bone dalam penegakan hukum yang berlaku dalam penyelenggaraan pemerintahannya, serta keterlibatan unsur non pemerintah dalam pembuatan kebijakan pemerintah, semuanya sudah terselenggara dengan baik. Lima puluh persen responden memberikan penilaian memuaskan.

Kata Kunci: Kesehatan; Pembagian Urusan Pemerintahan; Pemerintah Daerah

\section{A. Pendahuluan}

Sejak mula berdirinya, Republik Indonesia memang didesain oleh para pendiri negara sebagai Negara Kesatuan yang berbentuk Republik, yang mana kekuasaan pemerintahannya dipegang oleh Presiden. Namun karena heterogenitas yang dimiliki bangsa Indonesia, baik kondisi sosial, ekonomi, budaya, maupun keragaman tingkat pendidikan masyarakat, maka distribusi kewenangan dari pemerintah pusat perlu dialirkan kepada daerah yang otonom. Secara teoritis, pemberlakuan otonomi daerah merupakan langkah untuk meningkatkan pelayanan kepada masyarakat di daerah, sehingga kebutuhan masyarakat di daerah dapat terpenuhi. Dengan demikian otonomi daerah bukanlah tujuan tetapi suatu instrumen untuk mencapai tujuan. ${ }^{1}$ Sejak masa kemerdekaan sampai saat ini, distribusi kekuasaan/kewenangan dari pemerintah pusat ke pemerintah daerah selalu bergerak pada titik keseimbangan yang berbeda. Perbedaan ini sangat jelas terlihat dengan menggunakan konsep bandul yang selalu bergerak secara sistematis pada dua sisi yaitu pusat dan daerah. Dengan kata lain, bahwa pada

\footnotetext{
${ }^{1}$ Fesler, 1965; Leemans, 1970 dalam J. Kaloh, 2007, Mencari bentuk Otonomi Daerah Suatu Solusi dalam Menjawab Kebutuhan Lokal dan Tantangan Global, (rev.ed.), PT. Rineka Cipta, Jakarta, hal. 10.
} 
suatu waktu bobot kekuasaan terletak pada pemerintah pusat, pada kesempatan lain bobot kekuasaan ada pada pemerintah daerah. ${ }^{2}$ Hal demikian disebabkan karena undang-undang pemerintahan daerah dari masa kemerdekaan sampai saat ini selalu mengalami perubahan, dan juga disebabkan karena adanya perbedaan interpretasi dan implementasi terhadap undang-undang pemerintahan daerah yang disebabkan kepentingan penguasa pada masa berlakunya undang-undang pemerintahan daerah. Perkembangan ketatanegaraan Indonesia, otonomi yang diberikan kepada daerah itu memang mengalami pasang surut, pernah dengan formula "otonomi yang nyata dan bertanggungjawab"sebagaimana diatur dalam UU No. 5 Tahun 1974, "otonomi luas, nyata dan bertanggungjawab" dalam UU No. 22 Tahun 1999, dan "otonomi seluas-luasnya" pada Pasal 18 ayat (5) UUD 1945 dan UU No. 32 Tahun $2004 .{ }^{3}$ Pemberlakuan otonomi daerah atau desentralisasi di Indonesia yang dimaksudkan mampu menjaga heterogenitas bangsanya serta mampu meningkatkan pelayanan kepada masyarakat. Republik Indonesia kemudian dituntut untuk melakukan otonomi seluas-luasnya, namun tetap memberi batas kewenangan kepada daerah otonom yang selanjutnya diatur oleh undang-undang. ${ }^{4}$

Salah satu urusan pemerintahan daerah yang merupakan urusan pemerintahan wajib yang berkaitan dengan pelayanan dasar ialah urusan di bidang kesehatan, ${ }^{5}$ sebagaimana juga telah diamanahkan di dalam Undang-Undang Dasar Negara Republik Indonesia Tahun 1945 Pasal 28 H dan Undang-Undang Nomor 23 Tahun 1992 tentang Kesehatan, bahwa setiap orang berhak mendapatkan pelayanan kesehatan. Dengan demikian, setiap individu, keluarga, dan masyarakat Indonesia berhak memperoleh perlindungan kesehatannya. Karena kesehatan

2 Ibid, hal. 3.

${ }^{3}$ A Mukthie Fadjar, Prinsip NKRI, Otonomi Seluas-luasnya, Otonomi Khusus, Daerah Istimewa, dan Pemerintahan Sendiri Beberapa Catatan Atas RUU Pemerintahan Aceh. Di dalam Pemikiran Prof. Dr. Jimly Asshiddiqie, SH. dan Para Pakar Hukum, 2007, Konstitusi dan Ketatanegaraan Indonesia Kontemporer (Cetakan Pertama) The Biography Istitute, Bekasi, hal 269.

${ }^{4}$ Pasal 18 ayat (5) Undang-Undang Dasar Negara Republik Indonesi (UUD NRI) Tahun 1945: Pemerintahan daerah menjalankan otonomi seluas-luasnya, kecuali urusan pemerintahan yang oleh undang-undang ditentukan sebagai urusan Pemerintah Pusat.

${ }^{5}$ Pasal 12 ayat (1) huruf (b) Undang-Undang Nomor 23 Tahun 2014 Tentang Pemerintahan Daerah Juncto Undang-Undang Nomor 9 Tahun 2015 Tentang Perubahan Kedua Atas Undang-Undang Nomor 23 Tahun 2014 Tentang Pemerintahan Daerah. 
Jurnal Al-Adalah: Jurnal Hukum dan Politik Islam

Vol. 4, No. 1, Januari 2019:33-51

P-ISSN: 2406-8802

E-mail: aladalah@iain-bone.ac.id

http://jurnal.iain-bone.ac.id/index.php/aladalah

adalah hak asasi dan sekaligus investasi untuk keberhasilan pembangunan bangsa. ${ }^{6}$

Otonomi daerah di bidang kesehatan memberikan kesempatan kepada pemerintah daerah untuk mecipta kemampuan daerah dari berbagai aspek, mulai dari komitmen pemimpin dan masyarakat untuk membangun kesehatan, sistem kesehatan daerah, manajemen kesehatan daerah, dana, sarana, dan prasarana yang memadai, sehingga diharapkan kesehatan masyarakat di daerah menjadi lebih baik dan tinggi.

Dengan demikian, berangkat dari persoalan-persoalan mengenai hak warga negara untuk memperoleh perlindungan kesehatannya yang penyelenggaraannya didistribusikan dari pemerintah pusat kepada pemerintah daerah berdasarkan prinsip otonomi seluas-luasnya melalui Undang-Undang Nomor 23 tahun 2014 Tentang Pemerintah Daerah menggantikan UndangUndang Nomor 32 Tahun 2004 Tentang Pemerintahan Daerah, yang termasuk di dalamnya telah diatur ulang mengenai pembagian urusan. Atas dasar pijakan tersebut, maka penelitian ini bertujuan untuk mengetahui dan memahami politik hukum otonomi daerah dalam mewujudkan tata kelola pemerintahan yang baik pada bidang kesehatan di Kabupaten Bone, serta untuk mengetahui dan memahami penerapan prinsip tata kelola pemerintahan yang baik dalam penyelenggaraan urusan pemerintahan pada bidang kesehatan di kabupaten bone.

\section{B. Metode Penelitian}

\section{a. Tipe Penelitian dan Lokasi Penelitian}

Tipe penelitian yang digunakan dalam penulisan ini adalah penelitian hukum empiris (socio-legal research), yaitu penelitian hukum yang memperoleh data dari sumber data primer. Maka untuk memperoleh data yang berkaitan dengan penyelenggaraan tata kelola pemerintahan yang baik di bidang kesehatan, maka penenelitian ini dilakukan di Satuan Kerja Perangkat Daerah (SKPD) di bidang kesehatan, Dinas Kesehatan Kabupaten Bone.

\footnotetext{
${ }^{6}$ Saraswati R. 2012. Desain Sistem Pemerintahan Presidensial yang Efektif. Jurnal Masalah-Masalah Hukum (JMMH) Universitas Diponegoro. 41(1). hal 137-143.
} 


\section{b. Jenis dan Sumber Data}

Data yang diperoleh dan diolah dalam penelitian hukum empiris adalah data primer dan data sekunder. Data primer atau data mentah (raw data) diperoleh secara langsung di lapangan menggunakan teknik wawancara dan data ini masih perlu diolah lebih lanjut. Angket yang digunakan merupakan kuisioner langsung dan tertutup. Angket berupa deretan pernyataan dimana responden membubuhkan tanda centang pada kolom yang sesuai. Setiap kolom menunjukkan kategori sangat baik, baik, cukup baik, tidak baik, dan tidak menjawab. Data dianalisis dengan menghitung setiap jumlah kolom menggunakan persentase. Responden yang memberi penilaian terdiri dari tiga stakeholder, yaitu: pelaku usaha, masyarakat, dan pemerintah. Adapun data sekunder penelitian diperoleh berdasarkan studi kepustakaanberupa peraturan perundang-undangan dan artikel ilmiah.

\section{c. Analisis Data}

Hasil data yang diperoleh dianalisis secara deskriptif kualitatif. Bahan hukum primer maupun bahan hukum sekunder yang telah dikumpulkan dan dirumuskan berdasarkan topik permasalahan diklasifikasi menurut sumber dan hirarkinya yang untuk selanjutnya dijelaskan menurut hasil dari objek penelitian yang dikaji.

\section{Hasil Penelitian dan Pembahasan}

\section{a. Hasil Penelitian}

Secara yuridis urusan pemerintahan daerah di bidang kesehatan secara tegas baru dimuat sejak di undangkannya Undang-Undang Republik Indonesia Nomor 32 Tahun 2004 Tentang Pemerintahan Daerah yang telah menggantikan Undang-Undang Republik Indonesia Nomor 22 Tahun 1999 Tentang Pemerintahan Daerah yang selanjutnya juga mengalami perubahan sejak diundangkannya Undang-Undang Nomor 23 Tahun 2014 Tentang Pemerintahan Daerah. Dalam undang-undang tersebut memberikan wewenang kepada pemerintah daerah untuk mengatur, membiayai, dan melaksanakan urusan pemerintahan pada sektor kesehatan di daerah. Sejak diundangkannya UndangUndang Nomor 23 Tahun 2014 Tentang Pemerintahan Daerah menjadikan 
Jurnal Al-Adalah: Jurnal Hukum dan Politik Islam

Vol. 4, No. 1, Januari 2019:33-51

P-ISSN: 2406-8802

E-mail: aladalah@iain-bone.ac.id

http://jurnal.iain-bone.ac.id/index.php/aladalah

pelakasanaan otonomi daerah di Indonesia mengalami penyegaran karena undangundang yang lama dianggap tidak sesuai lagi dengan perkembangan keadaan, ketatanegaraan, dan tuntutan penyelenggaraan pemerintahan daerah. Prinsip otonomi dalam Undang-Undang Nomor 23 Tahun 2014 Tentang Pemerintahan Daerah tidak banyak mengalami perubahan dari Undang-Undang Nomor 32 Tahun 2004 Tentang Pemerintahan Daerah, yaitu prinsip otonomi seluas-luasnya dimana daerah diberikan kewenangan mengurus dan mengatur semua urusan pemerintahan di luar yang menjadi urusan pemerintah pusat yang ditetapkan dalam undang-undang. Perihal mengenai urusan pemerintahan konkuren selanjutnya terbagi atas urusan pemerintahan wajib dan urusan pemerintahan pilihan yang secara yuridis diatur dengan menggunakan skala prioritas bahwa urusan wajib yang berkaitan dengan pelayanan dasar diprioritaskan pelaksanaannya. Hal demikian dimaksudkan untuk memaksimalkan pelaksanaan penyelenggaraan pemerintahan di daerah, baik gubernur selaku wakil pemerintah pusat maupun pemerintah kabupaten/kota serta memperkuat status urusan otonomi daerah, mencegah tumpang tindih kewenangan serta efektivitas penyelenggaraan urusan pemerintahan daerah dan nasional.

\section{Gambar1.}

Pembagian Urusan Pemerintahan

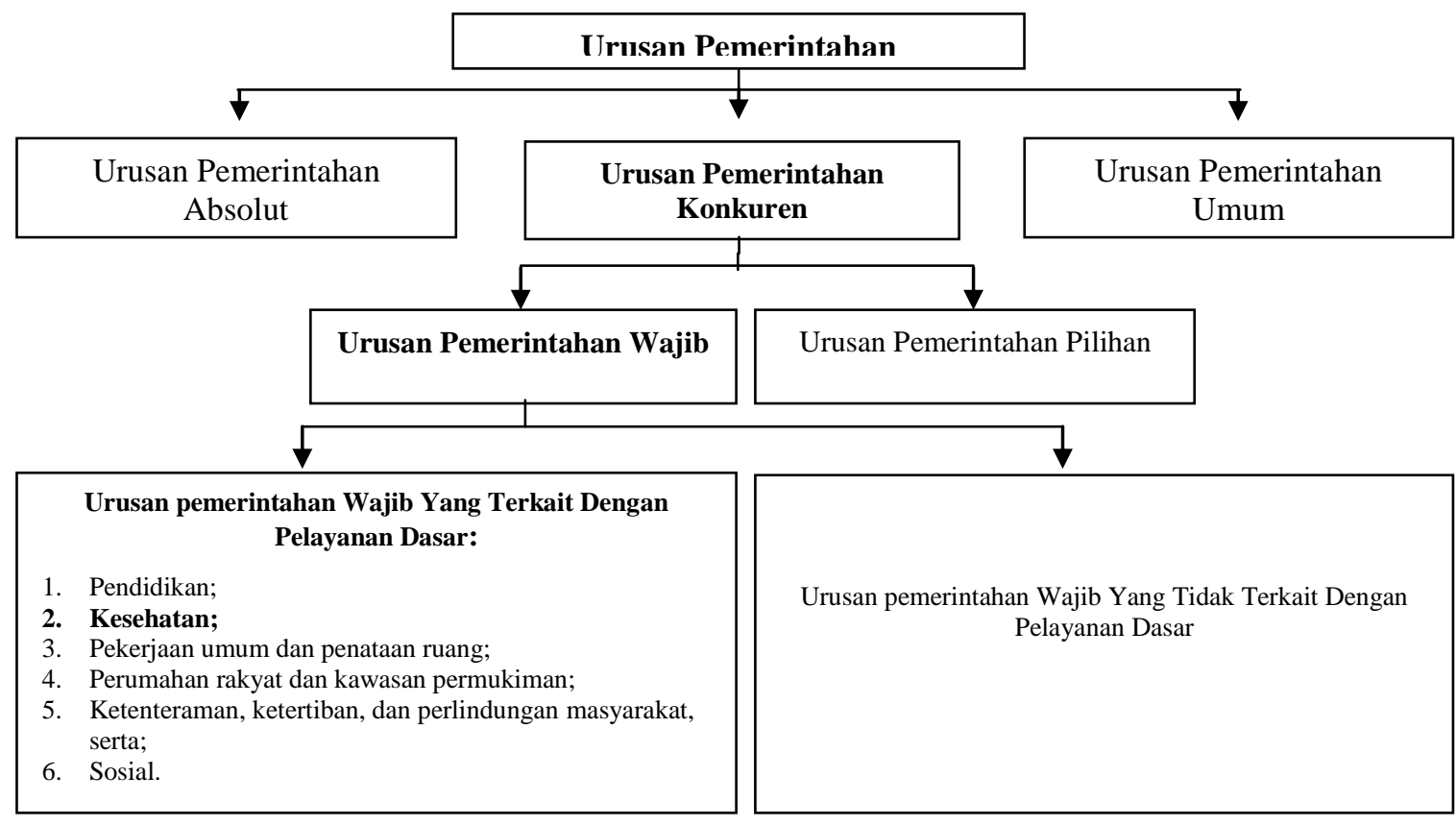


Berdasarkan uraian pada Gambar 1 menunjukkan bahwa penyelenggaraan urusan pemerintahan di bidang kesehatan yang juga dilaksanakan oleh Pemerintah Daerah Kabupaten Bone merupakan urusan pemerintahan yang dilaksanakan secara prioritas. Untuk itu Pemerintah Daerah Kabupaten Bone membentuk Dinas Kesehatan Kabupaten Bone sebagai unsur pelaksana di bidang kesehatan yang berkedudukan di bawah dan bertanggungjawab kepada Bupati melalui Sekretaris Daerah sebagaimana dalam Pasal 2, Pasal 3 ayat (9), dan Pasal 4 Peraturan Daerah Kabupaten Bone Nomor 3 Tahun 2008 Tentang Pembentukan Organisasi DinasDinas Daerah Kabupaten Bone. Untuk melaksanakan urusan pemerintahan di bidang kesehatan, Pemerintah Daerah Kabupaten Bone menyusun dan menetapkan Peraturan Daerah dan Peraturan Bupati yang mengatur tentang kesehatan.

Tabel 1.

Peraturan Daerah Kabupaten Bone Yang Mengatur Tentang Kesehatan

\begin{tabular}{|c|c|c|}
\hline No. & Peraturan Daerah & Materi Pengaturan \\
\hline 1. & $\begin{array}{l}\text { Peraturan Daerah Kabupaten } \\
\text { Bone Nomor } 1 \text { Tahun } 2008\end{array}$ & $\begin{array}{l}\text { Urusan Pemerintahan Yang Menjadi Kewenangan } \\
\text { Pemerintah Daerah Kabupaten Bone. }\end{array}$ \\
\hline 2. & $\begin{array}{l}\text { Peraturan Daerah Kabupaten } \\
\text { Bone Nomor } 2 \text { Tahun } 2009\end{array}$ & Penyelenggaraan Kesehatan Gratis \\
\hline 3. & $\begin{array}{l}\text { Peraturan Daerah Kabupaten } \\
\text { Bone Nomor } 4 \text { Tahun } 2009\end{array}$ & $\begin{array}{l}\text { Retribusi Pelayanan Kesehatan Pada Rumah Sakit } \\
\text { Umum Daerah Kabupaten Bone }\end{array}$ \\
\hline 4. & $\begin{array}{l}\text { Peraturan Daerah Kabupaten } \\
\text { Bone Nomor } 16 \text { Tahun } 2009\end{array}$ & Retribusi Pelayanan Kesehatan \\
\hline 5. & $\begin{array}{l}\text { Peraturan Daerah Kabupaten } \\
\text { Bone Nomor } 17 \text { Tahun } 2009\end{array}$ & $\begin{array}{l}\text { Perubahan Pertama Atas Peraturan Daerah } \\
\text { Kabupaten Bone Nomor } 18 \text { Tahun } 2003 \text { Tentang } \\
\text { Retribusi Kesehatan Rumah Sakit Swasta }\end{array}$ \\
\hline 6. & $\begin{array}{l}\text { Peraturan Daerah Kabupaten } \\
\text { Bone Nomor } 2 \text { Tahun } 2011\end{array}$ & Retribusi Jasa Umum \\
\hline 7. & $\begin{array}{l}\text { Peraturan Daerah Kabupaten } \\
\text { Bone Nomor } 4 \text { Tahun } 2014\end{array}$ & $\begin{array}{l}\text { Perubahan Atas Peraturan Daerah Kabupaten Bone } \\
\text { Nomor } 2 \text { Tahun } 2011 \text { Tentang Retribusi Jasa Umum }\end{array}$ \\
\hline 8. & $\begin{array}{l}\text { Peraturan Daerah Kabupaten } \\
\text { Bone Nomor } 8 \text { Tahun } 2014\end{array}$ & Inisiasi Menyusu Dini dan Air Susu Ibu Eksklusif \\
\hline
\end{tabular}

Tabel 2.

Peraturan Bupati Kabupaten Bone Yang Mengatur Tentang Kesehatan

\begin{tabular}{lll}
\hline No. & Peraturan Bupati & Materi Pengaturan \\
\hline 1. & Peraturan Bupati Kabupaten Bone & Standar Pelayanan Minimal \\
& Nomor 6 Tahun 2003 & Bidang Kesehatan Kabupaten Bone \\
2. & Peraturan Bupati Kabupaten Bone & Pelaksanaan PERDA Nomor 16 Tahun 2009 Tentang \\
& Nomor 15 Tahun 2010 & Retribusi Pelayanan Kesehatan \\
3. & Peraturan Bupati Kabupaten Bone & Penetapan Alokasi Dana Kesehatan Gratis Pada Badan \\
& Nomor 2 Tahun 2014 & Layanan Umum Daerah Rumah Sakit Umum Daerah
\end{tabular}


Jurnal Al-Adalah: Jurnal Hukum dan Politik Islam

Vol. 4, No. 1, Januari 2019:33-51

P-ISSN: 2406-8802

E-mail: aladalah@iain-bone.ac.id

http://jurnal.iain-bone.ac.id/index.php/aladalah

4. Peraturan Bupati Kabupaten Bone Nomor 24 Tahun 2014

5. Peraturan Bupati Kabupaten Bone Nomor 4 Tahun 2015

6. Peraturan Bupati Kabupaten Bone Nomor 5 Tahun 2015

7. Peraturan Bupati Kabupaten Bone Nomor 25 Tahun 2015

8. Peraturan Bupati Kabupaten Bone Nomor 30 Tahun 2015

Tenriawaru Kelas B Kabupaten Bone TahunAnggaran 2014

Penyelenggaraan Kabupaten Sehat Tingkat Kabupaten Bone

Peraturan Internal Rumah Sakit Umum Daerah

Tenriawaru

Standar Pelayanan Mininimal Rumah Sakit Umum Daerah

Tenriawaru

Pelaksanaan Sanitasi Total Berbasis Masyarakat

Besaran Alokasi Untuk Pelayanan Kesehatan dan Penegakan Hukum Yang Bersumber Dari Dana Bagi Hasil Penerimaan Pajak Rokok di Kabupaten Bone Kawasan Tanpa Rokok

9. Peraturan Bupati Kabupaten Bone Nomor 34 Tahun 2015

Sumber: Bagian Hukum Pemerintah Daerah Kabupaten Bone, 2018

Secara nyata Pemerintah Daerah Kabupaten Bone dalam melaksanakan urusan pemerintahan di bidang kesehatan yang menjadi kewenangannya harus berdasarkan pada pembagian urusan tersebut yang telah ditetapkan. Dengan demikian, secara otomatis Pemerintah Daerah Kabupaten Bone melaksanakan urusan pemerintahan di bidang kesehatan yang menjadi kewenangannya.

Tabel 3.

\section{Pelaksanaan Urusan Pemerintahan Daerah Kabupaten Bone di Bidang Kesehatan}

\begin{tabular}{|c|c|c|c|c|}
\hline No. & Urusan & Pemerintah Daerah Kabupaten/Kota & $\begin{array}{c}\text { Sudah } \\
\text { Dilaksan } \\
\text { akan }\end{array}$ & $\begin{array}{l}\text { Belum } \\
\text { Dilaks } \\
\text { anaka } \\
\text { n }\end{array}$ \\
\hline \multirow{3}{*}{1} & \multirow{3}{*}{$\begin{array}{l}\text { Upaya } \\
\text { Kesehatan }\end{array}$} & $\begin{array}{l}\text { Pengelolaan Upaya Kesehatan Perorangan (UKP) daerah } \\
\text { kabupaten/kota dan rujukan tingkat daerah kabupaten/kota. }\end{array}$ & $\checkmark$ & - \\
\hline & & $\begin{array}{l}\text { Pengelolaan Upaya Kesehatan Masyarakat (UKM) daerah } \\
\text { kabupaten/kota dan rujukan tingkat daerah kabupaten/kota. }\end{array}$ & $\checkmark$ & - \\
\hline & & $\begin{array}{l}\text { Penerbitan izin rumah sakit kelas } \mathrm{C} \text { dan } \mathrm{D} \text { dan fasilitas } \\
\text { pelayanan kesehatan tingkat daerah kabupaten/kota. }\end{array}$ & $\checkmark$ & - \\
\hline \multirow[b]{2}{*}{2} & \multirow{2}{*}{$\begin{array}{l}\text { Sumber Daya } \\
\text { Manusia } \\
(\text { SDM) } \\
\text { Kesehatan }\end{array}$} & Penerbitan izin paraktik dan izin kerja tenaga kesehatan. & $\checkmark$ & - \\
\hline & & $\begin{array}{l}\text { Perencanaan dan pengembangan SDM kesehatan untuk } \\
\text { UKM dan UKP daerah kabupaten/kota. }\end{array}$ & $\checkmark$ & - \\
\hline \multirow{5}{*}{3} & \multirow{5}{*}{$\begin{array}{l}\text { Sediaan } \\
\text { Farmasi, Alat } \\
\text { Kesehatan, dan } \\
\text { Makanan } \\
\text { Minuman }\end{array}$} & $\begin{array}{l}\text { Penerbitan izin apotek, toko obat, toko alat kesehatan dan } \\
\text { optikal. }\end{array}$ & $\checkmark$ & - \\
\hline & & Penerbitan izin usaha mikro obat tradional (UMOT). & - & $\checkmark$ \\
\hline & & $\begin{array}{l}\text { Penerbitan sertifikat produksi alat kesehatan kelas } 1 \text { (satu) } \\
\text { tertentu dan PKRT kelas } 1 \text { (satu) tertentu perusahaan rumah } \\
\text { tangga. }\end{array}$ & - & $\checkmark$ \\
\hline & & $\begin{array}{l}\text { Penerbitan izin produksi makanan dan minuman pada industri } \\
\text { rumah tangga. }\end{array}$ & $\checkmark$ & - \\
\hline & & $\begin{array}{l}\text { Pengawasan post-market produk makanan minuman industri } \\
\text { rumah tangga. }\end{array}$ & $\checkmark$ & - \\
\hline 4 & $\begin{array}{l}\text { Pemberdayaan } \\
\text { Masyarakat }\end{array}$ & $\begin{array}{l}\text { Pemberdayaan masyarakat bidang kesehatan melalui tokoh } \\
\text { kabupaten/kota, kelompok masyarakat, organisasi swadaya }\end{array}$ & $\checkmark$ & - \\
\hline
\end{tabular}




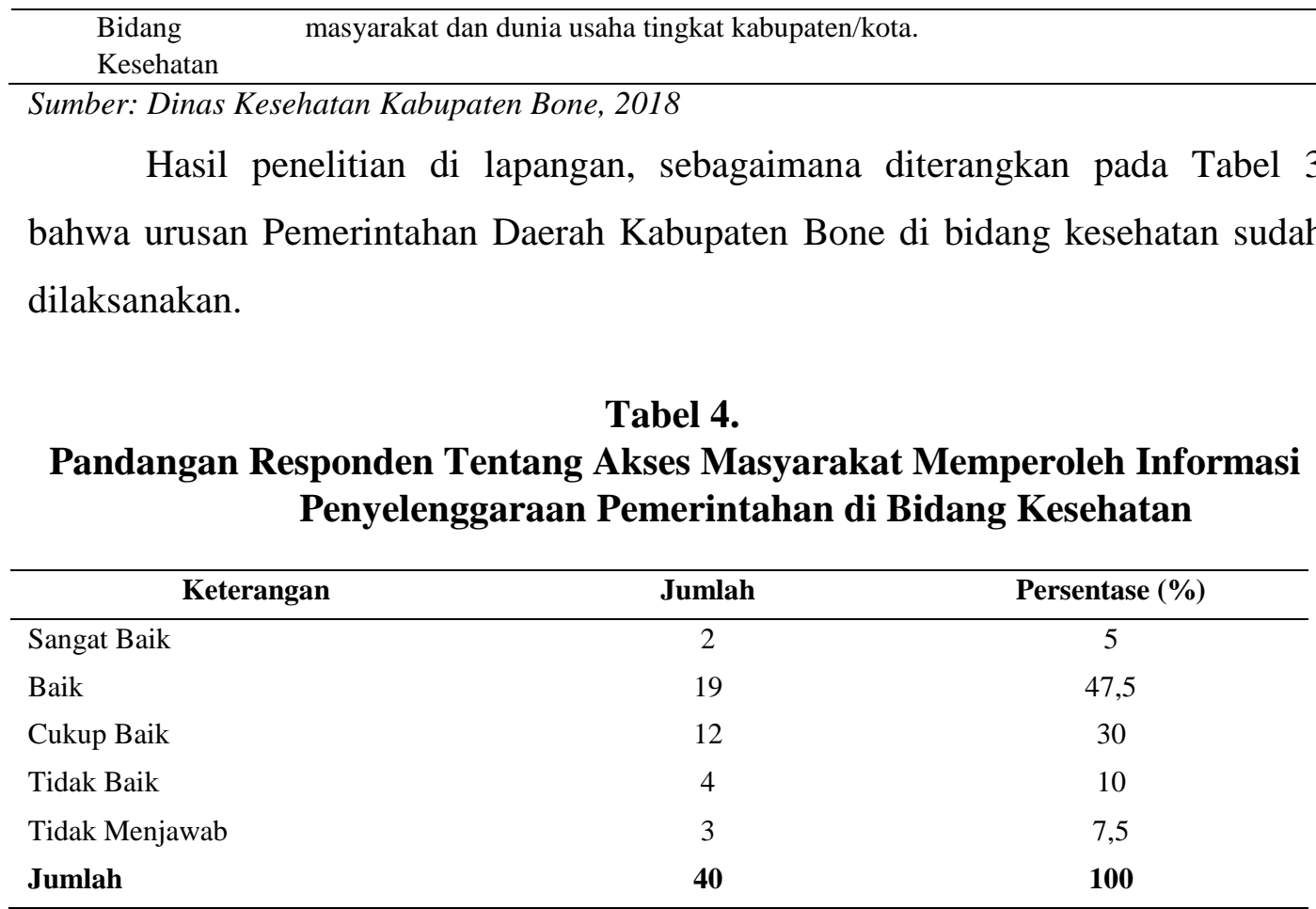

Sumber: Data Primer, 2018

Tabel 4 menunjukkan bahwa sebanyak $47.5 \%$ responden menyatakan akses masyarakat dalam memperoleh informasi terkait penyelenggaran pemerintahan di bidang kesehatan tergolong kategori baik. Pencapaian yang sama dengan persentase $50 \%$ juga diperoleh berdasarkan hasil wawancara responden terhadap kepercayaan masyarakat terhadap institusi pemerintah.

Tabel 5.

Pandangan Responden Tentang KepercayaanMasyarakat Terhadap Institusi Pemerintah (Khususnya di Bidang Kesehatan)

\begin{tabular}{lcc}
\hline \multicolumn{1}{c}{ Keterangan } & Jumlah & Persentase (\%) \\
\hline Sangat Baik & 8 & 20 \\
Baik & 20 & 50 \\
Cukup Baik & 6 & 15 \\
Tidak Baik & 4 & 10 \\
Tidak Menjawab & 2 & 5 \\
Jumlah & $\mathbf{4 0}$ & $\mathbf{1 0 0}$ \\
\hline Sumber: Data Primer, 2018 & &
\end{tabular}

Sumber: Data Primer, 2018

Adapun dari aspek aturan hukum, sebanyak 35\% responden menyatakan bahwa konsistensi Pemerintah Daerah Kabupaten Bone dalam penegakan hukum 
Jurnal Al-Adalah: Jurnal Hukum dan Politik Islam

Vol. 4, No. 1, Januari 2019:33-51

P-ISSN: 2406-8802

E-mail: aladalah@iain-bone.ac.id

http://jurnal.iain-bone.ac.id/index.php/aladalah

yang berlaku dalam penyelenggaraan pemerintahannya berada pada rentang baik dan cukup baik.

Tabel 6.

Pandangan Responden Tentang Konsistensi Pemerintah Daerah Kabupaten Bone dalam Penegakan Hukum yang Berlaku dalam Penyelenggaraan Pemerintahannya

\begin{tabular}{lcc}
\hline \multicolumn{1}{c}{ Keterangan } & Jumlah & Persentase (\%) \\
\hline Sangat Baik & 3 & 7,5 \\
Baik & 14 & 35 \\
Cukup Baik & 14 & 35 \\
Tidak Baik & 4 & 10 \\
Tidak Menjawab & 5 & 12,5 \\
Jumlah & $\mathbf{4 0}$ & $\mathbf{1 0 0}$ \\
\hline
\end{tabular}

Sumber: Data Primer, 2018

Dan untuk aspek partisipasi, sebanyak $47.5 \%$ responden menunjukkan bahwa keterlibatan unsur non pemerintah dalam pembuatan kebijakan pemerintah juga berada pada kategori baik.

Tabel 7.

Pandangan Responden Tentang Keterlibatan Unsur Non Pemerintah dalam Pembuatan Kebijakan Pemerintah (Khususnya di Bidang Kesehatan)

\begin{tabular}{lcc}
\hline \multicolumn{1}{c}{ Keterangan } & Jumlah & Persentase (\%) \\
\hline Sangat Baik & - & - \\
Baik & 19 & 47,5 \\
Cukup Baik & 13 & 32,5 \\
Tidak Baik & 4 & 10 \\
Tidak Menjawab & 4 & 10 \\
Jumlah & $\mathbf{4 0}$ & $\mathbf{1 0 0}$ \\
\hline
\end{tabular}

Sumber: Data Primer, 2018

Responden menyatakan memuaskan terhadap pandangan tentang tingkat kepuasan terhadap penyelenggaraan kewenangan Pemerintahan Daerah Kabupaten Bone di bidang kesehatan sebanyak $50 \%$.

Tabel 8.

Pandangan Responden Tentang Tingkat Kepuasan Terhadap Pelaksanaan Kewenangan Pada Urusan Kesehatan di Kabupaten Bone.

\begin{tabular}{lcc}
\hline \multicolumn{1}{c}{ Keterangan } & Jumlah & Persentase (\%) \\
\hline Sangat Memuaskan & - & - \\
Memuaskan & 20 & 50 \\
\hline
\end{tabular}




\begin{tabular}{lcc}
\hline Cukup Memuaskan & 11 & 27,5 \\
Tidak Memuaskan & 5 & 12,5 \\
Tidak Menjawab & 4 & 10 \\
Jumlah & $\mathbf{4 0}$ & $\mathbf{1 0 0}$ \\
\hline
\end{tabular}

Sumber: Data Primer, 2018

\section{Pembahasan}

Pada negara kesatuan dikenal dengan dua model sistem, yaitu sistem sentralisasi dan sistem desentralisasi. Dalam negara sistem sentralisasi, semua kebijakan diproses dan diselenggarakan oleh pemerintah pusat. Dengan demikian, pemerintah daerah hanya melaksanakan peraturan-peraturan dari pemerintah pusat saja. Daerah tidak memiliki kekuasaan untuk mengatur rumah tangganya sendiri. ${ }^{7}$ Adapun dalam negara kesatuan dengan sistem desentralisasi, daerah diberikan kekuaasaan untuk mengatur rumah tangga daerahnya, termasuk mengelola secara penuh Pendapatan Asli Daerah (PAD), dan Anggaran Pendapatan dan Belanja Daerah (APBD), berdasarkan inisiatif sendiri. Daerah seperti ini lazim disebut otonomi daerah (otoda) atau kekuasaan swatantra. ${ }^{8}$

Walaupun pada hakikatnya, negara kesatuan tidak terbagi atau dalam arti lain kekuasaan pemerintah pusat tidak dibatasi, karena konstitusi negara kesatuan tidak mengakui badan legislatif lain selain badan legislatif pusat. Jadi, kalaupun ada kewenangan bagi daerah, seperti membuat Peraturan Daerah (PERDA), tidak berarti bahwa pemerintah daerah itu berdaulat, karena pengawasan dan kekuasaan tertinggi masih tetap terletak di pemerintah pusat. ${ }^{9}$ Otonomi pada dasarnya merupakan konsep politik. Beberapa pengertian mengenai istilah ini, pada intinya apa yang dapat disimpulkan bahwa otonomi itu selalu dikaitkan atau disepadankan dengan pengertian kebebasan dan kemandirian. ${ }^{10}$ Sesuatu akan dianggap otonom, jika sesuatu itu dapat menentukan dirinya sendiri, membuat

\footnotetext{
7 Deddy Ismatullah. dan Asep A. Sahid Gatara Fh, Ilmu Negara Dalam Multi Perspektif. Cetakan kedua. CV. Pustaka Setia, Bandung, hal. 112-113.

${ }^{8}$ Ibid, hal. 113 .

${ }^{9}$ Ibid.

10 Koesoemahatmadja, 1979, Pengantar Ke Arah sistem Pemerintahan Daerah di Indonesia, Bina Cipta, Jakarta; Baca juga dalam Miftah Thoha, "Menejemen Pembangunan daerah Tingkat II" dalam Prisma, No. 12, 1985. Dalam M. Busrizalti, 2013, Hukum Pemda Otonomi Daerah dan Implikasinya, Cetakan Pertama, Total Media, Yogyakarta,hal. 70.
} 
Jurnal Al-Adalah: Jurnal Hukum dan Politik Islam

Vol. 4, No. 1, Januari 2019:33-51

P-ISSN: 2406-8802

E-mail: aladalah@iain-bone.ac.id

http://jurnal.iain-bone.ac.id/index.php/aladalah

hukum sendiri dengan maksud mengatur diri sendiri, dan berjalan berdasarkan kewenangan, kekuasaan, dan prakarsa sendiri. Muatan politis yang terkandung dalam istilah ini, adalah bahwa dengan kebebasan dan kemandirian tersebut, suatu daerah dianggap otonom kalau memiliki kewenangan (authority) atau kekuasaan (power) dalam penyelenggaraan pemerintahan terutama untuk menentukan kepentingan daerah dan masyarakatnya sendiri. ${ }^{11}$

Negara Indonesia, telah mengukuhkan keberadaan dirinya sebagai Negara Kesatuan Republik Indonesia, sebagaimana disebutkan pada Pasal 1 ayat (1) Undang-Undang Dasar Negara Republik Indonesia Tahun 1945 (UUD NRI 1945). Negara Kesatuan Republik Indonesia merupakan prinsip dasar dalam penyelenggaraan pemerintahan daerah, dimana konsepsi tersebut di satu sisi mengukuhkan keberadaan daerah sebagai bagian nasional, tetapi di sisi lain memberikan stimulan bagi masyarakat daerah untuk mengartikulasi semua kepentingannya, termasuk masalah otonomi daerah dalam sistem hukum dan kebijakan nasional. Idealnya tidak ada dan tidak mungkin terjadi suatu kebijakan nasional yang akan mengesampingkan, mengurangi, atau bahkan menghilangkan otonomi daerah. Hal ini disebabkan oleh adanya pemberian otonomi daerah yang telah menjadi bagian yang tak terpisahkan dari kebijakan nasional. Sebaliknya, daerah juga tidak dapat menafikkan jati dirinya sebagai bagian dari Negara Kesatuan Republik Indonesia, sehingga semua perilaku, kebijakan dan tindakan daerah tidak dapat bertentangan dengan kebijakan pusat. ${ }^{12}$

Di dalam negara kesatuan, tanggungjawab pelaksanaan tugas-tugas pemerintahan pada dasarnya tetap berada di tangan pemerintah. Akan tetapi karena sistem pemerintahan Indonesia, salah satunya menganut asas negara kesatuan yang didesentralisasikan, maka ada tugas-tugas tertentu yang diurus sendiri, sehingga menimbulkan hubungan timbal-balik yang melahirkan adanya hubungan kewenangan dan pengawasan. ${ }^{13}$

\footnotetext{
${ }^{11}$ Ibid.

${ }^{12}$ Hasrul M. 2013. Eksistensi Gubernur Sebagai Wakil Pemerintah Di Daerah Dalam Mewujudkan Pemerintahan Daerah Yang Efektif (Disertasi). Fakultas Hukum Universitas Hasanuddin, Makassar. hal. 30.

${ }^{13}$ Ibid, hal. 30-31.
} 
Otonomi daerah memiliki pijakan kuat dalam menjamin setiap daerah untuk memiliki hak yang otonom dan dijamin pelaksanaannya untuk dapat mengelola dan memaksimalkan pembangunan di daerah dengan keunikannya masing-masing. Bagi daerah yang daya saingnya belum memadai untuk berkompetisi, maka pemerintah berkewajiban memberikan dorongan agar daerah tersebut mampu berkembang sesuai dengan kondisi geografis, sosial budaya, dan ekonomi hingga mampu bersaing pada tingkatan persyaratan minimum. ${ }^{14}$

Desentralisasi bertujuan membangun partisipasi masyarakat dan mengundang keterlibatan publik seluas-luasnya dalam proses perencanaan, implementasi dan evaluasi pembangunan yang dijalankan. Untuk itu, desentralisasi memberikan ruang yang lebih luas kepada daerah untuk secara demokratis mengatur pemerintahannya sendiri sebagai manifestasi dari cita-cita sistem desentralisasi. ${ }^{15}$

Sistem pemerintahan di daerah pada dasarnya dapat diberi pengertian sebagai suatu kebulatan atau keseluruhan yang utuh yang di dalamnya terdapat komponen-komponen unit daerah yang mempunyai fungsi dan tugas dan saling terkait berdasarkan asas penyelenggaraan pemerintahan di daerah untuk mencapai tujuan daerah. Dalam konsep negara kesatuan, upaya mewujudkan keadilan dan kesejahteraan sosial sangat dipengaruhi oleh corak susunan masyarakat. Perbedaan sistem budaya dan kepercayaan, perbedaan sifat dan letak geografi, perbedaan latar belakang sejarah dan sebagainya. Perhatian terhadap perbedaan kekhususan tersebut, selanjutnya mengharuskan adanya perbedaan pelayanan dan cara penyelenggaraan pemerintahan. Adanya tuntutan penyelenggaraan pemerintahan semacam ini, hanya mungkin bisa terlaksana dalam sistem pemerintahan desentralistik.

Dengan demikian, Pemberlakuan otonomi daerah atau desentralisasi di Indonesia yang dimaksudkan mampu menjaga heterogenitas bangsanya serta mampu meningkatkan pelayanan kepada masyarakat. Sehingga Republik

\footnotetext{
${ }^{14}$ Ibid, hal. 47.

${ }^{15}$ Busrizalti H.M. 2013. Hukum Pemda Otonomi Daerah dan Implikasinya. Total Media. Yogyakarta
} 
Jurnal Al-Adalah: Jurnal Hukum dan Politik Islam

Vol. 4, No. 1, Januari 2019:33-51

P-ISSN: 2406-8802

E-mail: aladalah@iain-bone.ac.id

http://jurnal.iain-bone.ac.id/index.php/aladalah

Indonesia kemudian dituntut untuk melakukan otonomi seluas-luasnya, namun tetap memberi batas kewenangan kepada daerah otonom yang selanjutnya diatur oleh undang-undang sebagaimana yang telah amanahkan oleh Pasal 18 Ayat (5) Undang-Undang Dasar Negara Republik Indonesi (UUD NRI) Tahun 1945 bahwa Pemerintahan daerah menjalankan otonomi seluas-luasnya, kecuali urusan pemerintahan yang oleh undang-undang ditentukan sebagai urusan Pemerintah Pusat.

Penelitian ini menunjukkan bahwa penyelenggaraan tata kelola pemerintahan yang baik terhadap pelaksanaan urusan pemerintahan daerah di bidang kesehatan dimaksudkan memberikan pelayanan, keterlibatan, serta akses informasi kepada masyarakat terkait dengan kebijakan yang dilaksanakan oleh pemerintah. Dengan demikian, yang menjadi indikator penilaian dalam pembahasan ini ialah: 1) Tranparansi; 2) Akuntabilitas; 3) Aturan hukum; dan 4) Partisipasi.

Agar penyelenggaraan kesehatan bisa bersentuhan langsung kepada masyarakat maka dibutuhkan format penyelenggraan kewenangan yang bisa dilaksanakan pada tingkat daerah, untuk itu distribusi urusan pemerintahan di bidang kesehatan dari pusat kepada daerah otonom menjadi sebuah keniscayaan agar terwujud derajat kesehatan yang setinggi-tingginya bagi masyarakat. Berdasarkan Pasal 15 Peraturan Daerah Kabupaten Bone Nomor 3 Tahun 2008 Tentang Pembentukan Organisasi Dinas-Dinas Daerah Kabupaten Bone, Susunan Organisasi Dinas Kesehatan terdiri dari:

1. Kepala;

2. Sekretariat terdiri dari :

a. Sub Bagian Umum dan Perencanaan;

b. Sub Bagian Keuangan dan Perlengkapan;

c. Sub Bagian Kepegawaian;

3. Bidang Pelayanan Kesehatan terdiri dari :

a. Seksi Rumah Sakit \& Instalasi medis;

b. Seksi Puskesmas Kesehatan dan usia lanjut; 
4. Bidang Kesehatan Lingkungan dan Pencegahan Penyakit Menular terdiri dari :

a. Seksi Pembinaan Kesehatan Lingkungan;

b. Seksi Pengamatan \& Pencegahan penyakit;

5. Bidang Kesehatan Masyarakat dan Kesehatan Keluarga terdiri dari :
a. Seksi Kesehatan Ibu dan Anak;
b. Seksi Perbaikan gizi masyarakat;
c. Seksi Penyuluhan Kesehatan Masyarakat.

6. Bidang Pengawasan obat dan makanan terdiri dari :

a. Seksi Obat, Narkoba dan Makanan;

b. Seksi Pengawasan peredaran obat dan makanan

7. UPTD;

8. Kelompok Jabatan Fungsional.

Selanjutnya, untuk melaksanakan urusan pemerintahan di bidang kesehatan, Pemerintah Daerah Kabupaten Bone menyusun dan menetapkan peraturan daerah dan peraturan bupati yang mengatur tentang kesehatan (Lihat Tabel 1 dan Tabel 2).

Pada aspek transparansi, Pemerintah Daerah Kabupaten Bone dalam hal ini Dinas Kesehatan Kabupaten Bone telah meluncurkan layanan informasi dan pengaduan berbasis elektronik (website). Laman website tersebut diluncurkan bertujuan agar segala kegiatan pemerintah daerah yang berkaitan dengan kesehatan bisa diketahui dan diakses secara bebas oleh masyarakat luas khususnya untuk masyarakat Kabupaten Bone serta sebagai sarana pengaduan masyarakat terkait dengan pelayanan kesehatan. Dengan demikian, untuk sarana pengaduan terhadap pelayanan, masyarakat mendapatkan akses penuh untuk mengadukan kepada Kepala Dinas Kesehatan Kabupaten Bone apabila di setiap Pusat Kesehatan Masyarakat (PKM) terjadi proses pelayanan yang tidak sesuai dengan standar dan prinsip pelayanan kesehatan di Kabupaten Bone.

Peluncuran laman website resmi Dinas Kesehatan Kabupaten Bone sejalan dengan prinsip transparansi dalam pemenuhan tata kelola pemerintahan yang baik khususnya di bidang kesehatan yang di bangun dalam rangka membuka ruang 
Jurnal Al-Adalah: Jurnal Hukum dan Politik Islam

Vol. 4, No. 1, Januari 2019:33-51

P-ISSN: 2406-8802

E-mail: aladalah@iain-bone.ac.id

http://jurnal.iain-bone.ac.id/index.php/aladalah

serta aliran informasi yang bebas dan mudah di akses. Dengan demikian, akses masyarakat untuk memperoleh informasi mengenai urusan penyelenggaraan pemerintahan di bidang kesehatan pada lingkup pemerintahan daerah di Kabupaten Bone tergolong baik (Tabel 4). Hal tersebut disebabkan oleh kemajuan dan kemudahan untuk mengakses jaringan internet. Transparansi harus dibangun dalam rangka kebebasan aliran informasi.

Dari sisi akuntabilitas, selaku Satuan Kerja Perangkat Daerah (SKPD) di bidang kesehatan, Dinas Kesehatan Kabupaten Bone melakukan evaluasi kebijakan dalam kurun waktu satu bulan sekali yang diantaranya pelaporan capaian penyelenggaraan program kebijakan. Hal tersebut dimaksudkan agar setiap kebijakan yang ditetapkan harus bisa dipertanggungjawabkan.

Dengan demikian, tingkat kepercayaan masyarakat terhadap institusi pemerintahan yang membidangi urusan kesehatan tergolong baik (Tabel 5). Hal tersebut disebabkan pada setiap Rumah Sakit dan UPTD Pusekesmas di Kabupaten Bone menyediakan papan informasi yang memuat tentang hasil evaluasi capaian kinerja terhadap kebijakan yang belum maupun yang sudah dilaksanakan.

Pada tataran normatif kerangka aturan hukum dan perundang-undangan harus berkeadilan, ditegakkan, dan dipatuhi secara utuh, terutama yang mengatur mengenai Hak Asasi Manusia (HAM); merupakan kriteria dari prinsip aturan hukum yang dianut dalam mewujudkan tata kelola pemerintahan yang baik.

Keberadaan aturan hukum yang memadai, salah satu yang menjadi indikator penilaian dari variabel penyelenggaraan tata kelola pemerintahan yang baik di bidang kesehatan ialah Konsistensi Pemerintah Daerah Kabupaten Bone dalam penegakan hukum yang berlaku dalam penyelenggaraan pemerintahannya. Sejalan dengan prinsip aturan hukum tersebut, Pemerintah Daerah Kabupaten Bone dalam menyusun dan menetapkan kebijakan yang akan dilaksanakan tetap berada di dalam koridor hukum sebagai wujud dari implementasi bahwa Negara Kesatuan Republik Indonesia adalah Negara hukum (Tabel 6).

Selanjutnya pada aspek tingkat partisipasi masyarakat dalam wujud peningkatan derajat kesehatan masyarakat di Kabupaten Bone, telah dibentuk 
suatu Forum Kabupaten Bone Sehat sebagai penyelenggara berbagai kegiatan berbasis kesehatan dengan memberdayakan masyarakat yang difasilitasi oleh Pemerintah Daerah Kabupaten Bone. Adapun unsur-unsur keanggotaan Forum kabupaten Bone Sehat, meliputi: unsur masyarakat dan tokoh masyarakat; unsur pemerintah; unsur swasta; unsur LSM; unsur perguruan tinggi; unsur media massa.

Berdasarkan penelitian di lapangan, peneliti mengukur keterlibatan unsur non pemerintah dalam pembuatan kebijakan pemerintah (khususnya di bidang kesehatan) dengan melibatkan responden dari unsur pemerintah, swasta, dan tokoh masyarakat (Tabel 7). Dengan demikian, keterlibatan unsur non pemerintah dalam pembuatan kebijakan pemerintah (khususnya di bidang kesehatan) tergolong baik. Hal tersebut disebakan oleh sinergitas antara unsur pemerintah dan non pemerintah dalam berpartisiapasi untuk mewujudkan Kabupaten Bone Sehat, baik pada saat penyusunan kebijakan, evaluasi kinerja, sampai dengan sosialisasi kesehatan.

Uraian pada tabel-tabel di atas menggambarkan bahwa penyelenggaraan tata kelola pemerintahan yang baik terhadap urusan pemerintahan daerah di bidang kesehatan sudah terselenggara dengan baik. Selaras dengan tujuan otonomi daerah, penyelenggaraan pemerintahan daerah diarahkan untuk mempercepat terwujudnya kesejahteraan masyarakat melalui peningkatan pelayanan, pemberdayaan, dan peran serta masyarakat, serta peningkatan daya saing daerah dengan memperhatikan prinsip demokrasi, pemerataan, keadilan, dan kekhasan suatu daerah dalam sistem Negara Kesatuan Republik Indonesia.

Dengan demikan, untuk mengetahui pengaruh politik hukum otonomi daerah terhadap penyelenggaraan tata kelola pemerintahan yang baik di bidang kesehatan, peneliti mengukur tingkat kepuasan responden mengenai pelakasanaan urusan di bidang kesehatan yang dilaksanakan oleh Pemerintah Daerah Kabupaten Bone berdasarkan Undang-Undang Nomor 23 Tahun 2014 tentang Pemerintahan Daerah. Dari gambaran pada Tabel 8, menurut hemat peneliti bahwa pelaksanaan politik hukum otonomi daerah berpengaruh positif terhadap penyelenggaraan tata kelola pemerintahan yang baik di bidang kesehatan. 
Jurnal Al-Adalah: Jurnal Hukum dan Politik Islam

Vol. 4, No. 1, Januari 2019:33-51

P-ISSN: 2406-8802

E-mail: aladalah@iain-bone.ac.id

http://jurnal.iain-bone.ac.id/index.php/aladalah

Pelaksanaan pemerintahan yang baik menurut United Nations Development Program (UNDP) mampu mendorong perkembangan sosial masyarakat sehingga terbentuk kesejahteraan integritas dan kohesivitas sosial dalam masyarakat. Kemudian menurut Prasetijo (2015), good governance adalah tata pemerintahan yang baik atau menjalankan fungsi pemerintahan yang baik, bersih dan berwibawa (struktur, fungsi, manusia, aturan, dan lain-lain). Sehingga bisa dikatakan bahwa prinsip penyelenggaran pemerintahan pada bidang kesehatan di Kabupaten Bone sesuai dengan prinsip-prinsip good governance menurut UNDP dimana aspek partisipasi, transparansi, aturan hukum dan akuntabilitas sudah terpenuhi dengan baik. Dalam menyelenggarakan tugas pemerintahan, ditentukan adanya keterlibatan beberapa unsur sebagai stakeholder, tidak terbatas pada pemerintah atau negara saja, tetapi juga dari unsur non pemerintah dan masyarakat. Sehingga kepemerintahan (good governance) dapat tercipta dengan baik apabila unsur-unsur yang dimaksud sebagai kekuatan yang bersinergi dan saling mendukung serta memilki suara dalam mempengaruhi pembuatan suatu keputusan. ${ }^{16}$

\section{E. Kesimpulan dan Saran}

Politik hukum otonomi daerah dalam mewujudkan tata kelola pemerintahan yang baik pada bidang kesehatan di Kabupaten Bone didasari oleh hak atas perlindungan kesehatan bagi setiap warga negara yang mutlak diberikan oleh negara yang pelaksanaannya melibatkan unsur pemerintahan daerah. Penerapan prinsip tata kelola pemerintahan yang dalam penyelenggaraan urusan pemerintahan pada bidang kesehatan di Kabupaten Bone diukur berdasarkan akses masyarakat memperoleh informasi penyelenggaraan pemerintahan, kepercayaan masyarakat terhadap institusi pemerintah, konsistensi dalam penegakan hukum, serta keterlibatan unsur non pemerintah dalam pembuatan kebijakan pemerintah (khususnya di bidang kesehatan). Pemerintah Daerah Kabupaten Bone hendaknya terus mengupayakan sosialisasi dan pembinaan kepada masyarakat mengenai

\footnotetext{
${ }^{16}$ Amin M.N. 2008. Penerapan Prinsip-Prinsip Good Governance Dalam Meningkatkan Efektivitas Kepemimpinan Pada Kantor Wilayah Depatemen Hukum dan Ham Provinsi Sulawesi Tengah (Tesis). Fakultas Hukum Universitas Hasanuddin, Makassar
} 
kebijakan penyelenggaraan kesehatan. Untuk meningkatkan kesadaran, kepedulian, dan sinergitas antara pemerintah dengan masyarakat.

\section{DAFTAR PUSTAKA}

Amin M.N. 2008. Penerapan Prinsip-Prinsip Good Governance Dalam Meningkatkan Efektivitas Kepemimpinan Pada Kantor Wilayah Depatemen Hukum dan Ham Provinsi Sulawesi Tengah (Tesis). Makassar: Fakultas Hukum Universitas Hasanuddin.

Busrizalti H.M. 2013. Hukum Pemda Otonomi Daerah dan Implikasinya. Yogyakarta: Total Media.

Hasrul M. 2013. Eksistensi Gubernur Sebagai Wakil Pemerintah Di Daerah Dalam Mewujudkan Pemerintahan Daerah Yang Efektif (Disertasi). Makassar: Fakultas Hukum Universitas Hasanuddin Makassar.

Ismatullah D. \& Gatara A.A.S. 2007. Ilmu Negara dalam Multi Perspektif. Cetakan kedua. Bandung: CV. Pustaka Setia.

Jimly Asshiddiqie dan Para Pakar Hukum. 2007. Konstitusi dan Ketatanegaraan Indonesia Kontemporer Pemikiran Prof. Jimly Asshiddiqie, S.H. dan Para PakarHukum. Cetakan Pertama. Bekasi: The Biography Institute.

Kaloh J. 2007. Mencari bentuk Otonomi Daerah Suatu Solusi dalam Menjawab Kebutuhan Lokal dan Tantangan Global. Edisi Revisi. Jakarta: PT. Rineka Cipta.

Koesoemahatmadja D.R.H. 1979. Pengantar Ke Arah sistem Pemerintahan Daerah di Indonesia. Jakarta: Bina Cipta.

Kurnia T.S. 2007. Hak Atas Derajat Kesehatan Optimal Sebagai HAM di Indonesia. Edisi Pertama. Bandung: PT. Alumni.

Marzuki P.M. 2009. Penelitian Hukum. Cetakan Kelima. Jakarta: Kencana.

Nawi H.S. 2014. Penelitian Hukum Normatif Versus Penelitian Hukum Empris. Makassar: PT. Umitoha Ukhuwah Grafika.

Saraswati R. 2012. Desain Sistem Pemerintahan Presidensial yang Efektif. Jurnal Masalah-Masalah Hukum (JMMH) Universitas Diponegoro. 41(1).p 137143.

Soedjono \& Abdurrahman H. 2003. Metode Penelitian Hukum. Jakarta: Rineka Cipta.

Sukardja A. 2012. Hukum Tata Negara dan Administrasi Negara dalam Perspektif Fiqih Siyasah. Cetakan Pertama. Jakarta: Sinar Grafika.

Tanya B.L. 2011. Politik Hukum Agenda Kepentingan Bersama. Yogyakarta: Genta Publishing. 